\title{
Mišljenje studenata i prvostupnika fizioterapije o teorijskoj i praktičnoj nastavi
}

1 Dora Jurički

1 Olivera Petrak

1 Snježana Schuster

${ }^{1}$ Zdravstveno veleučilište Zagreb

\section{Sažetak}

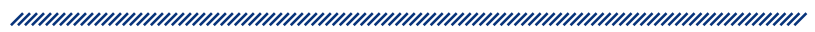

Uvod: „Fizioterapeut mora posjedovati određena znanja i vještine..." Ova fraza odnosi se na stručne kompetencije potrebne za adekvatnu fizioterapijsku procjenu pacijenta, na postavljanje ciljane dijagnoze na temelju procjene te na provođenje fizioterapijske intervencije. Naglašava da je u obrazovanju učenje teorije jednako važno kao i svladavanje praktičnog dijela profesije.

Cilj rada: Utvrditi koliko studenti tijekom obrazovanja smatraju zadovoljavajućima i usklađenima teorijske i vježbovne sadržaje iz struke te postoji li značajna razlika u mišljenju studenata treće godine u odnosu apsolvente i prvostupnike fizioterapije.

Metode: Istraživanje je provedeno sa studentima i prvostupnicima fizioterapije Zdravstvenog veleučilišta u Zagrebu (ZVU) 2019. godine. Sudjelovalo je 88 ispitanika, podijeljenih u dvije skupine. Prvu skupinu činili su apsolventi i studenti sa završenim preddiplomskim studijem, a drugu skupinu studenti treće godine redovnog studija fizioterapije. $U$ trenutku ispunjavanja ankete studenti druge skupine odrađivali su kliničku nastavu.

Rezultati: Ispitanici smatraju kako bi na praktična znanja trebalo staviti veći naglasak te da postoji neusklađe- nost znanja koje dobivaju u edukaciji i praktičnog rada s kojim se susreću na radilištima. Mišljenja su kako bi bilo kvalitetnije da praksa iz određenog predmeta slijedi neposredno nakon teorijskog upoznavanja s predmetom te im je važan individualni angažman svakog studenta. Prva skupina u većoj mjeri smatra da im je potrebno dodatno usavršavanje osnovnih praktičnih vještina, kao i da je nužno usklađivanje znanja nastavnika i mentora.

Zaključak: Rezultati ovog istraživanja pokazuju da je povećana potreba za unaprjeđenjem aktualnih teorijskih i praktičnih znanja u cilju napredne fizioterapijske prakse uz otvaranje mogućnosti jedinstvenog kurikuluma za obrazovanje budućih prvostupnika fizioterapije u Hrvatskoj. Zlatni standard u edukaciji budućih fizioterapeuta postiže se, uz poboljšanje kvalitete edukacije studenata i edukacijom predavača i mentora.

Ključne riječi: fizioterapija, teorija, praksa, studenti, kurikulum

Datum primitka: 29.03.2021.

Datum prihvaćanja: 15.04.2021.

https://doi.org/10.24141/1/7/2/7

Adresa za dopisivanje:

Dora Jurički

A: Mali Sruki 64, 10040 Zagreb

E-pošta: dora.juricki@gmail.com

T.: +385919475462 


\section{Uvod}

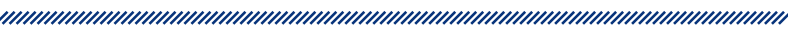

„Fizioterapeut mora posjedovati određena znanja i vještine..." Ova fraza odnosi se na stručne kompetencije potrebne za provedbu adekvatne fizioterapijske procjene pacijenta, na postavljanje ciljane dijagnoze na temelju procjene te na provođenje fizioterapijske intervencije. Odnosi se također na komunikaciju s pacijentima, njihovim obiteljima i ostalim članovima tima za dobrobit pacijenta, kao i na edukaciju ostalih članova tima, obitelji pacijenta i pacijenta samog za što brži oporavak i što veću do maksimalnu samostalnost pacijenta nakon otpusta. Znanja i vještine fizioterapeuta odnose se na vođenje dokumentacije o oblicima intervencije, parametrima i posljedicama intervencije u smislu funkcionalnog statusa (opseg pokreta, jakost, izdržljivost...). Fizioterapeut mora posjedovati određena znanja i vještine za provođenje istraživanja u fizioterapiji i sudjelovanje u izobrazbi studenata. ${ }^{1} \mathrm{U}$ frazi je navedeno kako je u obrazovanju studenta učenje teorije jednako važno kao i svladavanje praktičnog dijela profesije, odnosno vještine rada. Značajno je razmatranje razlika i sličnosti u teoriji i praksi u izobrazbi studenata fizioterapije.

\section{Teorija i praksa}

Riječ teorija dolazi od grčke riječi $\vartheta \varepsilon \omega \rho i \alpha$ (od glagola

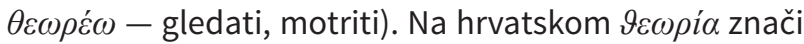
gledanje, razmatranje, uviđanje, spoznavanje. ${ }^{2}$ Svaka znanstvena hipoteza, ako se potvrdi novim empirijskim činjenicama, postaje teorija. ${ }^{3}$ Teorija se konkretno u ovome radu odnosi na teorijski dio nastavnog kurikuluma uključujući predavanja, seminare i kabinetske vježbe. Prema Roskell i suradnicima, riječ teorija dobiva značenje fraze za teorijska (edukacijska), teoretska pitanja, kao i pitanja u istraživačkim radovima koja imaju minimalno doticaja s onim što se događa na licu mjesta u praksi. ${ }^{4}$ Pojam praksa potječe od grčke riječi $\pi \rho \tilde{\alpha} \xi ı \varsigma$ i znači djelovanje. Objašnjava se, za razliku od teorije, kao izvršavanje stvari, radnja, posao, konkretan rad. ${ }^{5}$

Prema dostupnim izvorima informacija, u Republici Hrvatskoj provodi se 14 studijskih programa fizioter- apije, na državnim te na privatnim sveučilištima i veleučilištima. Od toga se šest studija provodi za izvanredne studente, a osam studija za redovne studente. ${ }^{6}$ S obzirom na to da je riječ o 14 različitih studija, iako su neki za izvanredne i redovne studente na istoj obrazovnoj instituciji, riječ je o 14 kurikuluma koji se izjednačavaju po programu što se tiče samih predmeta zbog svjetske standardizacije, ali i o 14 različitih kurikuluma po broju sati teorijskog dijela nastave (uključujući seminare i kabinetske vježbe) te po broju praktičnog dijela nastave (kliničke vježbe - praksa). Tako je, primjerice, na jednom preddiplomskom studiju (redovnom) fizioterapije oko 940 sati predavanja u tri godine, ${ }^{7}$ dok je na drugom, također redovnom smjeru studija približno 1030 sati predavanja, ${ }^{8}$ a na trećem otprilike 850 sati predavanja u tri godine. ${ }^{9}$ Uzevši u obzir seminare, brojke se razlikuju od 210 do 882 sati seminarske nastave. Tako se također razlikuju i sati kabinetskih vježbi. Dok je na jednom studiju 510 sati vježbi, na drugom je ili trećem oko 490 sati.

S druge strane, praksa u fizioterapiji označava primjenu teoretskih znanja na konkretnim situacijama u svakodnevnom profesionalnom okruženju. Isto tako, pojam praksa u ovome kontekstu označava laički termin za kliničke vježbe studenata na kliničkim stanicama, u bolnicama, privatnim klinikama i domovima zdravlja. Općenito, studenti na preddiplomskom studiju fizioterapije kroz tri godine studija bivaju na mnogobrojnim stanicama u klinikama i bolnicama. S obzirom na to da nijednom studijskom programu nije u cilju izvođenje kliničkih vježbi koje se ne mogu povezati s teorijskom nastavom kroz tri godine preddiplomskog stručnog studija fizioterapije, studenti odrađuju kliničke vježbe paralelno s temama odslušane teorije. Pri tome, kako količina i kompleksnost sadržaja teorije iz godine u godinu raste, tako ujedno raste količina sati kliničkih vježbi. Uspoređujući sate kliničkih vježbi na raznim studijima redovnih smjerova fizioterapije u Republici Hrvatskoj ${ }^{7-9}$ može se uočiti kako na prvoj godini ima najmanje sati kliničkih vježbi (između 60 i 90), na drugoj godini nešto više (oko 165 sati) te na trećoj godini ima najviše sati kliničkih vježbi koje studenti imaju obvezu odraditi (između 360 i 470 sati), što je logičan slijed upoznavanja s kliničkim oblicima rada prema stjecanju znanja na studijskim godinama.

Za primjenu kvalitetne procjene pacijentova funkcionaInog deficita, analize i same terapije teorijska je podloga temelj, ali nije superiornija u odnosu na praksu i obrnuto. Za kvalitetno fizioterapeutsko djelovanje nužna je vještina koju studenti tijekom studija svladavaju kroz 
vježbe u kabinetskim oblicima izvedbe nastave i kroz kliničku vježbovnu nastavu, odnosno praksu. Teorija čini $70 \%$, čak gotovo $80 \%$ studija. Praksa, odnosno kliničke vježbe čine manje od $30 \%$ sveukupnoga nastavnog kurikuluma na studijima fizioterapije u Republici Hrvatskoj. S obzirom na to da kliničke vježbe (praksa) prate teorijski dio nastave, svakog semestra studenti odlaze na druge kliničke stanice koje su usko povezane sa svladanom teorijskom nastavom.

Tijekom prve godine studija studenti kliničke vježbe provode na različitim kliničkim bazama (radilištima), gdje ih se nastoji upoznati sa strukom, odnosno uvesti u svijet fizioterapeuta. Spoznaje se djelokrug rada fizioterapeuta, uloga fizioterapeuta u fizioterapiji današnjice. Predstavljaju se različiti fizioterapijski pristupi. Primjenjuje se fizioterapijska procjena te sve njezine sastavnice (anamneza, opservacija, palpacija, antropometrijska mjerenja, mjere opsega pokreta, mjerenje mišićne jakosti putem testova te mjerenje aerobnog kapaciteta i izdržljivosti). Studenti rade procjenu posture, procjenu aktivnosti svakodnevnog života, procjenu hoda, lokomocije i ravnoteže.

Druga godina studija uključuje odlazak na praksu u cilju primjene fizioterapije iz područja fizikalnih čimbenika, primjenu elektrodijagnostičkih postupaka, provođenje terapijskih vježbi u okviru fizioterapijskog programa. Studente se upoznaje s funkcionalnim treningom brige o sebi i domaćinstvu. Demonstrira se primjena ortoza, proteza, adaptivnih, zaštitnih i potpornih sredstava te opreme. Kroz praksu na drugoj godini studija naglasak je na upoznavanju studenata s kliničkim medicinskim znanostima, a time i provedbom kliničkih procjena i intervencija.

Treća godina temelji se na primjeni kliničke fizioterapije. Klinička fizioterapija uključuje primjenu kliničke nastave na različitim kliničkim odjelima specifičnima za neurologiju, kardiologiju, pulmologiju, ortopediju, pedijatriju, traumatologiju, pulmologiju, onkologiju, reumatologiju, ginekologiju i opstetriciju. Osim kliničke fizioterapije, kliničke vježbe (praksa) treće godine uglavnom uključuju primjenu fizioterapije u sportu, fizioterapije kod osoba s amputacijom ili nekim drugim invaliditetom. Primjenjuje se fizioterapija koja prikazuje potrebe kod osoba starije životne dobi. ${ }^{10}$

\section{Cilj istraživanja}

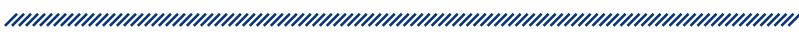

Cilj je rada utvrditi koliko studenti povezuju odnose između teorijskih i praktičnih sadržaja u visokom obrazovanju budućih studenata fizioterapije. Osim toga, dodatni cilj odnosi se na provjeru razlika u odgovorima između studenata koji su završili studij u potpunosti ili su već apsolventi u odnosu na studente koji u trenutku provođenja ankete još nisu u potpunosti završili studijski program. Uz to, želi se saznati postoji li razlika u rezultatima s obzirom na spol.

\section{Materijali i metode}

\section{Opis uzorka i postupak}

Istraživanje je provedeno na prigodnom uzorku studenata studija fizioterapije i prvostupnika Zdravstvenog veleučilišta u Zagrebu (nadalje ZVU) prvom polovicom 2019. godine na Veleučilištu i putem online komunikacije. Za izradu rada pripremljena je anketa za navedenu vrstu istraživanja. Za istraživanje je dobivena suglasnost Etičkog povjerenstva Zdravstvenog veleučilišta u Zagrebu 28. veljače 2019. Studenti uključeni u istraživanje završili su studij 2018./2019. godine i u trenutku provedbe ankete bili su na stažu ili na apsolventskoj godini (nadalje prva skupina). Druga skupina studenata u trenutku provedbe istraživanja bila je na trećoj godini redovnog studija fizioterapije također na ZVU-u (nadalje druga skupina). Prva skupina studenata uključivala je 52 sudionika, dok je druga skupina studenata uključivala 36 sudionika. Zajedno su činili ukupan broj od 88 sudionika (69 studentica i 19 studenata). Dob studenata obje skupine u prosjeku iznosi 24,63 godine s rasponom od 21 do 29 godina. Najčešća je dob sudionika 22 godine. Sudjelovalo je 69 studentica $(78,4 \%)$ i 19 studenata (21,6\%). Srednju školu za fizioterapeutskog tehničara pohađao je 21 ispitanik (23,9\%).

Svi ispitanici uključeni u istraživanje bili su upoznati s načinom provedbe istraživanja, anketa je bila anonimna te su studenti i prvostupnici dobrovoljno sudjelovali u ovom istraživanju. Anketa s prvom skupinom studenata i prvostupnika provedena je putem interneta uz 
prethodno objašnjenje svrhe istraživanja te potrebnih uputa za ispunjavanje ankete. Anketa s drugom skupinom studenata provedena je na dva načina. Prvi način sadržavao je odlazak na dva predavanja te osobno ispunjavanje ankete na papiru, a drugi način ispunjavanje ankete putem interneta kao i kod prve skupinom ispitanika. U primjeni online ankete, anketa nije bila anonimna za istraživača, međutim sudionicima je zajamčena povjerljivost podataka.

Provjera normalnosti distribucija Shapiro-Wilkovim testom pokazala je da se raspodjela odgovora za svaku tvrdnju razlikuje statistički značajno od normalne distribucije (za sve tvrdnje P iznosi 0,000) te ćemo u inferencijalnoj statistici primijeniti neparametrijske postupke. U deskriptivnoj ćemo uz medijan, prikazati i aritmetičku sredinu zbog njezine veće preciznosti.

\section{Instrumentarij}

Za potrebe ovog istraživanja izrađena je anketa koja se sastoji od dva dijela. Prvi dio ankete sadržava četiri pitanja o osobnim informacijama o spolu, dobi, jesu li sudionici pohađali srednju školu za fizioterapeutskog tehničara i jesu li odradili ili trenutačno odrađuju staž. Pitanja o pohađanju srednje škole za fizioterapeutskog tehničara, kao i činjenice o pohađanju staža relevantne su zbog moguće povezanosti s rezultatima istraživanja. Studenti koji su završili srednjoškolsko obrazovanje za fizioterapeutskog tehničara imali su nešto više praktične nastave na kliničkim bazama nego studenti koji nisu pohađali spomenutu srednju školu. Nadalje, iz tog istog razloga anketa se provodila s dvije skupine studenata odvojeno. Studenti koji su pripadali prvoj skupini studenata imaju završene sve sastavnice predmeta kliničke vježbe na klinikama, dok je studentima druge skupine ostao još jedan semestar odrađivanja kliničke nastave.

Drugi dio ankete sastoji se od 16 pitanja zatvorenog tipa koja su bila napisana u obliku tvrdnji. Sudionici su odgovarali na tvrdnje zadanom skalom odgovora (zaokruživanjem jednog broja od 1 do 5). Broj 1 označava da se sudionik uopće ne slaže s napisanom tvrdnjom, dok broj 5 označava slaganje s napisanom tvrdnjom u potpunosti. Prve dvije tvrdnje obuhvaćaju pitanja koja su usmjerena prema određivanju stava studenata o povezanosti teorijske nastave koja uključuje predavanja, seminare, kabinetske vježbe i kliničke vježbe (praksu) na kliničkim bazama (radilištima). Iduća četiri pitanja odnose se na mišljenje studenata o opremljenosti kliničkih baza bilo da su one zdravstvene bilo privatne zdravstvene ustanove i ima li fizioterapeut adekvatnu količinu vremena za provođenje adekvatne fizioterapije s obzirom na radno mjesto. Pitanja od 7 . do 12. odnose se na mišljenje studenata o svladanom teorijskom i praktičnom znanju, odnosno je li i u kojoj količini svladano znanje dovoljno za nastavak samostalnog rada studenta po završetku studija. U kolikoj se mjeri studenti slažu ili ne slažu s trenutačnom organizacijom nastave, kao i o važnosti povezanosti između profesora teorijske (predavanja, seminari, kabinetske vježbe) i praktične nastave (kliničke vježbe - praksa) saznajemo u posljednje četiri tvrdnje.

\section{Rezultati}

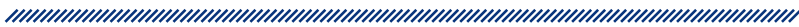

U tablici 1 prikazani su osnovni parametri deskriptivne statistike za 16 tvrdnji na cijelom uzorku.

Željeli smo saznati mišljenje studenata o povezanosti teorijske nastave (koja uključuje predavanja, seminare i vježbe) s kliničkom nastavom (koja uključuje kliničke vježbe - praksu na kliničkim bazama - državne i privatne zdravstvene ustanove), što se ispituje prvim dvjema tvrdnjama. Studenti se uglavnom slažu da postoji dobra povezanost teorijskih sadržaja sa sadržajima na kabinetskim vježbama. Suprotno tome, kod većine studenata prevladava mišljenje da se kabinetska vježbovna nastava ne podudara s kliničkom nastavom (praksom). Drugim riječima, studenti doživljavaju sadržaje koje slušaju u krugu svoje obrazovne institucije (predavanja, seminari, kabinetske vježbe) prilično konzistentnima i usklađenima, no to ne vrijedi pri usporedbi kabinetske nastave i kliničke nastave na praksi.

Studenti su uglavnom suzdržani oko 7. i 8. tvrdnje (je li trenutačna količina teorije i prakse (vještina) dovoljna za usvajanje potrebnog znanja za rad studenta po završetku studija). No iz odgovora na 9. i 10. tvrdnju može se primijetiti prevladavanje stajališta studenata da je potrebno više se fokusirati na praktična znanja. Studenti se uglavnom slažu da se na praksi najviše praktičnog znanja postiže individualnim angažmanom svakog studenta. Unatoč tome, ispitanici smatraju da je potrebno dodatno stručno usavršavanje izvan propisanog plana i programa.

Prema studijskom programu, klinička nastava (praksa) slijedi nakon odslušanog semestra (predavanja, semi- 


\section{Tablica 1. Deskriptivna statistika pojedinih čestica skale stavova sudionika $(\mathbf{N}=\mathbf{8 8})$}

\begin{tabular}{|c|c|c|c|c|c|}
\hline TVRDNJA & $\bar{M}$ & C & IR & Min. & Maks \\
\hline $\begin{array}{l}\text { 1. U predmetima gdje postoji kabinetska vježbovna nastava (vježbe) u potpunosti postoji } \\
\text { povezanost između teorijskih sadržaja s izvedbom vježbovne nastave. }\end{array}$ & 3,55 & 4 & 1 & 2 & 5 \\
\hline 2. Kabinetska vježbovna nastava (vježbe) podudara se izvedbom s kliničkom nastavom (praksa). & 2,78 & 3 & 1 & 1 & 4 \\
\hline $\begin{array}{l}\text { 3. Svaka državna zdravstvena ustanova (bolnica, ambulanta) u potpunosti je opremljena } \\
\text { potrebnim sredstvima za provođenje adekvatne fizioterapije. }\end{array}$ & 2,34 & 2 & 1 & 1 & 5 \\
\hline $\begin{array}{l}\text { 4. Svaka privatna zdravstvena ustanova u potpunosti je opremljena potrebnim sredstvima } \\
\text { za provođenje adekvatne fizioterapije. }\end{array}$ & 3,92 & 4 & 0 & 1 & 5 \\
\hline $\begin{array}{l}\text { 5. Fizioterapeut zaposlen u državnoj zdravstvenoj ustanovi ima mogućnost posvećivanja } \\
\text { potrebnog vremena svakom pacijentu za izvođenje adekvatne terapije. }\end{array}$ & 2,02 & 2 & 2 & 1 & 4 \\
\hline $\begin{array}{l}\text { 6. Fizioterapeut zaposlen u privatnoj zdravstvenoj ustanovi ima mogućnost posvećivanja } \\
\text { potrebnog vremena svakom pacijentu za izvođenje adekvatne terapije. }\end{array}$ & 4,20 & 4 & 1 & 3 & 5 \\
\hline $\begin{array}{l}\text { 7. Količina teorijske nastave dovoljna je za usvajanje potrebnog znanja za daljnji rad } \\
\text { studenta po završetku studija. }\end{array}$ & 2,65 & 3 & 1 & 1 & 5 \\
\hline $\begin{array}{l}\text { 8. Količina kliničke nastave (praksa) dovoljna je za usvajanje potrebnog znanja za daljnji rad } \\
\text { studenta po završetku studija. }\end{array}$ & 2,50 & 3 & 1 & 1 & 4 \\
\hline 9. Potrebno je više se fokusirati na teorijska znanja. & 2,44 & 2 & 1 & 1 & 5 \\
\hline 10. Potrebno je više se fokusirati na praktična znanja. & 4,69 & 5 & 1 & 3 & 5 \\
\hline $\begin{array}{l}\text { 11. Tijekom kliničkih vježbi (prakse) najviše praktičnog znanja postižemo individualnim } \\
\text { angažmanom svakog studenta ponaosob. }\end{array}$ & 4,22 & 4 & 1 & 2 & 5 \\
\hline $\begin{array}{l}\text { 12. Potrebno je dodatno usavršavanje osnovnih praktičnih vještina izvan satnice propisane } \\
\text { studijskim planom i programom. }\end{array}$ & 4,34 & 4 & 1 & 3 & 5 \\
\hline $\begin{array}{l}\text { 13. Organizacija nastave gdje bi praksa iz određenog predmeta slijedila neposredno nakon } \\
\text { odslušanih predavanja i vježbi bila bi adekvatnija od postojeće. }\end{array}$ & 4,41 & 5 & 1 & 1 & 5 \\
\hline 14. Postojeća je organizacija nastave gdje praksa slijedi nakon odslušanog semestra adekvatna. & 3,22 & 3 & 1 & 1 & 5 \\
\hline 15. Nužna je koordinacija predaje znanja između profesora teorije i mentora na praksi. & 4,55 & 5 & 1 & 3 & 5 \\
\hline 16. Konzultacije profesora teorije i mentora na praksi nisu potrebne za prenošenje znanja. & 1,82 & 2 & 1 & 1 & 5 \\
\hline
\end{tabular}

nari, kabinetske vježbe). Pitali smo ispitanike za njihovo mišljenje o postojećoj organizaciji nastave (14. tvrdnja). Odgovori ne pokazuju konkretan stav o kvaliteti trenutačne organizacije nastave. Međutim, čak 77 studenata uglavnom se ili u potpunosti slaže da bi provođenje prakse odmah nakon odslušane kabinetske nastave bilo adekvatnije u odnosu na postojeće stanje (13. tvrdnja) (grafikon 1). Najveće slaganje dobiveno je za 10., 15. i 13. tvrdnju, što ukazuje da studenti smatraju kako bi na praktična znanja trebalo staviti veći naglasak, odnosno ukazuje na stanovitu neusklađenost znanja koje dobivaju u edukaciji i praktičnog rada s kojim se susreću na radilištima. Također, mišljenja su kako bi bilo kvalitetnije da praksa iz određenog predmeta slijedi neposredno nakon teorijskog upoznavanja s predmetom.

Ispitanici se najmanje slažu sa 16., 5. i 3. tvrdnjom. Smatraju da su konzultacije nastavnika i mentora od velike važnosti, da zdravstveni sustav nije ni vremenski ni opremom adekvatno prilagođen radnim obvezama fizioterapeuta. U 15. i 16. tvrdnji pokušalo se saznati kakvo je mišljenje studenata o potrebi koordinacije, odnosno konzultacija o predaji znanja između predavača teorijske nastave i mentora (asistenata na kliničkim bazama - radilištima) na praksi. Oba pitanja govore o istoj tvrdnji, ali su postavljena na dva različita načina kako bi se provjerila dosljednost u odgovaranju. Obje tvrdnje ukazuju na visoko slaganje studenata da je koordinacija znanja predavača teorije i mentora na praksi nužna.

Između ostalog, bilo nam je zanimljivo vidjeti kakvo je mišljenje studenata i prvostupnika o razlici državnih i privatnih zdravstvenih ustanova. Studenti Zdravstvenog veleučilišta u Zagrebu prolaze razne kliničke baze tijekom kliničke nastave (prakse). Kliničke su baze (radilišta) uključene u proces edukacije budućih fiziote- 


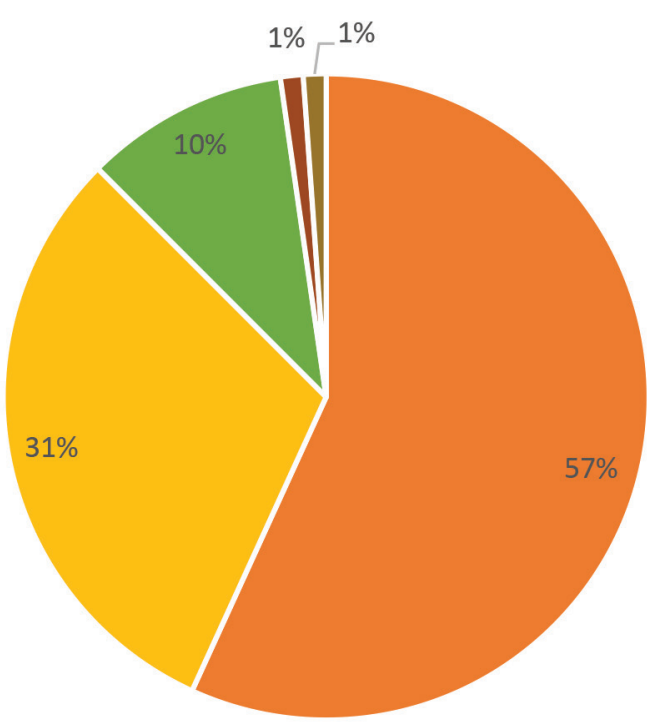

- U potpunosti se slažem

- Uglavnom se slažem

- Niti se slažem niti ne slažem

- Uglavnom se ne slažem

- U potpunosti se ne slažem

Grafikon 1. Postotak odgovora na 13. tvrdnju - Organizacija nastave gdje bi praksa iz određenog predmeta slijedila neposredno nakon odslušanih predavanja i vježbi bila bi adekvatnija $(\mathbf{N}=\mathbf{8 8})$

rapeuta ili državne ili privatne zdravstvene ustanove. Tvrdnje pod rednim brojevima od 3. do 6. odnose se na razlike između državnih zdravstvenih ustanova (koje uključuju bolnice i ambulante) i privatnih zdravstvenih ustanova. Studenti znatno pozitivnije procjenjuju stanje u privatnim zdravstvenim ustanovama u odnosu na državne; smatraju da su privatne ustanove bolje opremljene za provođenje adekvatne fizioterapije te da fizioterapeuti imaju veću mogućnost posvećivanja svakom pacijentu ponaosob.

Osim stavova cijele skupine, zanimale su nas i eventualne razlike u mišljenjima ispitanika s obzirom na njihov spol, srednju školu i stupanj odrađene prakse. Sve su usporedbe provedene Mann-Whitneyjevim U-testom. Za spol, bez obzira na to je li osoba pripadala prvoj ili drugoj skupini, utvrđeno je da ne postoji statistički značajna razlika ni za jednu od 16 tvrdnji (razina značajnosti jest $0,05)$. S obzirom na to jesu li ispitanici pohađali srednju školu za fizioterapeutskog tehničara (21 osoba) ili ne (67) dobivena je značajna razlika samo za 4. tvrdnju (Mann-Whitneyjev U iznosi 498 uz $\mathrm{P}=0,025$ ): ispitanici koji nisu išli u navedenu srednju školu imaju značajno pozitivniji stav o opremljenosti privatnih zdravstvenih ustanova. No s obzirom na veliki nerazmjer broja sudionika u podskupinama po spolu i po srednjoj školi, ove analize treba uzeti aproksimativno.

S obzirom na stupanj odrađene prakse, ispitanici su podijeljeni u dvije skupine. Obje skupine čine sadašnji odnosno bivši studenti (na stažu) preddiplomskog studija fizioterapije u Zagrebu. U prvu skupinu spadaju apsolventi ili prvostupnici sa završene tri godine preddiplomskog studija, dakle, u trenutku provođenja ankete imali su odrađenih 705 sati kliničke prakse $(N=52)$. Druga je skupina u trenutku ispunjavanja ankete bila u posljednjem semestru studija te je još morala odraditi 240 sati kliničke prakse $(\mathrm{N}=36)$. Zanimalo nas je razlikuju li se dvije promatrane skupine značajno u svojim odgovorima.

Vidimo da je statistički značajna razlika dobivena za šest tvrdnji od ukupno 16 s obzirom na razliku u stupnju obrazovanja sudionika (tablica 2). Ispitanici u prvoj skupini izraženijeg su negativnog mišljenja o opremljenosti potrebnim sredstvima za provođenje adekvatne fizioterapije u javnim zdravstvenim ustanova, dok je kod druge skupine prevladao neutralan stav (3. tvrdnja). U petoj tvrdnji također postoji statistički značajna razlika u rezultatima, no obje se skupine uglavnom slažu da fizioterapeut nema mogućnost posvećivanja potrebnog vremena svakom pacijentu ponaosob za provođenje adekvatne terapije, pri čemu prva skupina u značajno većoj mjeri.

Studenti uključeni u istraživanje koji su završili cjelokupni program preddiplomskog studija fizioterapije ili su tad trenutačno bili u procesu odrađivanja ili imali odrađen staž (prva skupina) pretežno se ne slažu s tvrdnjom da je količina kliničke nastave dovoljna za usvajanje potrebnog znanja za rad studenta po završetku studija (8. tvrdnja). Studenti koji su tada još uvijek bili u 


\begin{tabular}{|c|c|c|c|c|c|}
\hline TVRDNJA & SKUPINA & M & C & Man-Whitneyjev U & $\mathrm{P}$ \\
\hline \multirow{2}{*}{$\begin{array}{l}\text { 3. Svaka državna zdravstvena ustanova (bolnica, ambulanta) u } \\
\text { potpunosti je opremljena potrebnim sredstvima za provođenje } \\
\text { adekvatne fizioterapije. }\end{array}$} & 1. & 2,15 & 2 & \multirow{2}{*}{653,5} & \multirow{2}{*}{0,011} \\
\hline & 2. & 2,61 & 3 & & \\
\hline \multirow{2}{*}{$\begin{array}{l}\text { 5. Fizioterapeut zaposlen u državnoj zdravstvenoj ustanovi ima } \\
\text { mogućnost posvećivanja potrebnog vremena svakom pacijentu za } \\
\text { izvođenje adekvatne terapije. }\end{array}$} & 1. & 1,88 & 2 & \multirow{2}{*}{712,0} & \multirow{2}{*}{0,042} \\
\hline & 2. & 2,22 & 2 & & \\
\hline \multirow{2}{*}{$\begin{array}{l}\text { 8. Količina kliničke nastave (praksa) dovoljna je za usvajanje } \\
\text { potrebnog znanja za daljnji rad studenta po završetku studija. }\end{array}$} & 1. & 2,31 & 2 & \multirow{2}{*}{677,0} & \multirow{2}{*}{0,021} \\
\hline & 2. & 2,78 & 3 & & \\
\hline \multirow{2}{*}{ 9. Potrebno je više se fokusirati na teorijska znanja. } & 1. & 2,23 & 2 & \multirow{2}{*}{680,5} & \multirow{2}{*}{0,024} \\
\hline & 2. & 2,75 & 3 & & \\
\hline \multirow{2}{*}{$\begin{array}{l}\text { 12. Potrebno je dodatno usavršavanje osnovnih praktičnih vještina } \\
\text { izvan satnice propisane studijskim planom i programom. }\end{array}$} & 1. & 4,50 & 5 & \multirow{2}{*}{674,0} & \multirow{2}{*}{0,014} \\
\hline & 2. & 4,11 & 4 & & \\
\hline \multirow{2}{*}{$\begin{array}{l}\text { 16. Konzultacije profesora teorije i mentora na praksi nisu potrebne } \\
\text { za prenošenje znanja. }\end{array}$} & 1. & 1,60 & 1 & \multirow{2}{*}{642,0} & \multirow{2}{*}{0,007} \\
\hline & 2. & 2,14 & 2 & & \\
\hline
\end{tabular}

procesu školovanja nisu imali pretjerano izraženo negativno mišljenje o toj tvrdnji, odnosno prva skupina smatra kako u studijskom programu ne postoji dovoljan broj sati kliničke nastave (prakse). Suprotno tome, kod prve skupine prevladava mišljenje da nije potrebno više se fokusirati na teorijska znanja (9. tvrdnja). U drugoj skupini ponovno je u rezultatima prevladao neutralniji stav. lako u 9. tvrdnji postoji značajna razlika, očekivalo se kako će razlika postojati i u srodnoj 10. tvrdnji koja navodi da je potrebno više se fokusirati na praktična znanja. Unatoč tome, iako su studenti druge skupine ostali neodređenog mišljenja oko fokusa na teorijska znanja, svi su se ispitanici u potpunosti složili da je potrebno više se fokusirati na praktična znanja. Značajna razlika dobivena je i za 12. tvrdnju. lako se obje skupine slažu da je potrebno dodatno usavršavanje osnovnih praktičnih vještina izvan propisanog studijskog programa, prva skupina izražava značajno veće slaganje (ili značajno pozitivnije mišljenje).

Prva skupina u značajno većoj mjeri smatra da su konzultacije nastavnika i mentora na praksi potrebne radi prenošenja znanja.

\section{Rasprava}

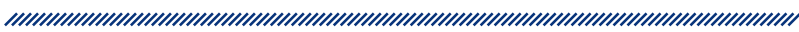

\section{Povezanost teorije i prakse}

Ispitanici u prvoj skupini u trenutku provođenja ankete imali su više praktičnog iskustva s obzirom na stupanj obrazovanja od studenata druge skupine (treće godine) te nas je zanimalo je li to povezano s razlikom u njihovim mišljenjima.

Podaci s različitih visokoobrazovnih institucija za fizioterapeute omogućuju uvid u trenutačni odnos teorije i prakse u obrazovanju fizioterapeuta u RH. Kao što je već rečeno, postoji 14 različitih studijskih programa fizioterapije u Hrvatskoj. Prema dostupnim podacima s mrežnih stranica obrazovnih institucija u RH koje se odnose na programe za buduće fizioterapeute u visokom obrazovanju, vidljivo je da su satnice izvedbe različitih oblika nastave uglavnom slične, a znatnije razlike mogu se uočiti u navedenim primjerima prikazanima u tablici $3 .^{7-9}$ 


\begin{tabular}{|c|c|c|c|c|}
\hline STUDIJ & PREDAVANJA & SEMINARI & KABINETSKE VJEŽBE & KLINIČKE VJEŽBE \\
\hline A & 850 & 882 & 494 & 705 \\
\hline B & 940 & 210 & 510 & 630 \\
\hline C & 1032 & 816 & 357 & 630 \\
\hline
\end{tabular}

Navedeni podaci preuzeti su iz aktualnih baza podataka na javno dostupnim mrežnim stranicama pojedinih obrazovnih institucija u visokom obrazovanju fizioterapeuta za sve tri godine redovnog smjera preddiplomskog studija fizioterapije.-9 Kako bi se bolje uočila važnost kliničke vježbovne nastave (prakse) u odnosu na ostale teorijske oblike nastave, nastava putem predavanja, seminara i kabinetskih vježbi prikazuje se kao teorijski dio nastave, dok će vježbovni dio nastave biti onaj koji se odnosi na kliničku vježbovnu nastavu (praksu). Na studiju A (Libertas međunarodno sveučilište, preddiplomski sveučilišni studij fizioterapije) teorijski dio nastave iznosi $76 \%$ sveukupne nastave, dok kliničke vježbe (praksa) čine samo $24 \%$. Na studiju B (Zdravstveno veleučilište Zagreb, preddiplomski stručni studij fizioterapije) teorijski dio nastave iznosi $72,5 \%$, a kliničke vježbe iznose $27,5 \%$. Na studiju C (Fakultet zdravstvenih studija Sveučilišta u Rijeci, preddiplomski stručni studij fizioterapije) teorijski dio nastave čini $77,8 \%$ sveukupne nastave, dok kliničke vježbe iznose samo $22,2 \%$. Na svim studijskim programima teorija zauzima većinu plana i programa, dok kliničke vježbe pokrivaju manje od $30 \%$ sveukupne nastave. Zdravstveno veleučilište Zagreb (B) ima statistički značajno manje sati teorijske nastave (predavanja, seminari i kabinetske vježbe) u odnosu na ostale dvije ustanove $\left(\chi^{2}=19,499 ; \mathrm{df}=2 ; \mathrm{P}=0,0000\right)$.

Preddiplomski studij (razina entry levela u fizioterapiji - 180 ECTS) priprema studente teorijski i praktično za samostalan rad u zdravstvenim ustanovama. Studijski programi osposobljavaju prvostupnika fizioterapije za provođenje postupaka unutar fizioterapijskog procesa (fizioterapijske procjene, određivanje ciljeva fizioterapijskog tretmana, identifikaciju problema, određivanje plana fizioterapijskog tretmana). Fizioterapeut prvostupnik može provoditi terapijske vježbe, tehnike manualne terapije, respiratornu terapiju, elektroterapiju, posjeduje znanja i vještine za apliciranje pomagala, može upotrebljavati fizikalne agense. Vještine fizioterapeuta također uključuju mehaničke terapijske postupke i provođenje funkcionalnog treninga brige o sebi i do- maćinstvu. Ključna je edukacija pacijenta i pacijentove obitelji, koordinacija i komunikacija s članovima tima te vođenje dokumentacije. Na kraju će fizioterapeut biti sposoban za primarnu, sekundarnu i tercijarnu razinu prevencije ozljeda, oštećenja, funkcionalnih ograničenja i onesposobljenja.

Rezultati provedenog istraživanja, u koje je bilo uključeno 88 studenata i prvostupnika, pokazuju da bi se više trebalo fokusirati na praktična znanja pri edukaciji studenata. Odnosno, iako su teorijski sadržaji bogato upotpunjeni, studenti smatraju kako praktična znanja podosta zaostaju za teorijom. Na primjer, studenti su suglasni da postoji dobra povezanost između teorijske podjele nastave na predavanja, seminare i kabinetske vježbe $(M=3,55)$, dok podudaranje između teorijskih sadržaja i nastave na kliničkim bazama (prakse) nije toliko izraženo ( $M=2,78)$. Također smatraju kako bi bila adekvatnija organizacija nastave kada bi praksa iz određenog predmeta slijedila neposredno nakon odslušanih predavanja i kabinetskih vježbi $(M=4,41)$. Nakon ovih saznanja i planiranih kompetencija za koje bi prvostupnik fizioterapije trebao biti osposobljen, još uvijek postoji mogućnost da je nejasno dobivaju li studenti ono što im je obećano od edukacije. U tom slučaju postoji nekoliko tvrdnji koje nam mogu pružiti zadovoljavajući odgovor na to pitanje. Tvrdnje 7. i 8. ispituju je li količina nastave, bilo teorijske bilo praktične, dovoljna za samostalan rad po završetku studija. Vidljivo je da su obje promatrane skupine (apsolventi i prvostupnici fizioterapije u odnosu na studente treće godine) neodlučne je li teorijski dio nastave dovoljan za daljnji rad $\left(M_{1}=2,65\right.$; $\left.M_{2}=2,64\right)$. Usprkos tome, prva skupina bila je značajno izraženijeg negativnog mišljenja oko pitanja praktične nastave. Druga je skupina i tu neutralnijeg stava, ali je u trenutku provođenja ankete imala i manje praktičnog znanja od prve skupine. Prva skupina uglavnom smatra da količina kliničke nastave (prakse) nije dovoljna za daljnji rad studenta po završetku studija.

Ispitanici iz prve skupine izjavljuju da im nedostaje prakse, iako su odradili više sati prakse. Razlozi za to mogu biti dvojaki: s jedne strane, približavaju se svijetu 
rada, pa tu raste bojazan oko toga kako će se u njemu snaći, a s druge su strane svjesni da je njihovo obrazovanje pri kraju te imaju bolji uvid u to koliko im je ono dovoljno za kvalitetno obavljanje posla fizioterapeuta. Moguće je da stažisti ulaskom u svijet rada doživljavaju „šok realnosti” koji se javlja kada imaju očekivanja koja nisu u skladu s iskustvima na radnom mjestu. ${ }^{11}$

Druga skupina nije još gotova sa svojim preddiplomskim obrazovanjem te ispitanici ni nemaju potpunu percepciju kakva će sve znanja steći i koja će radilišta obići do kraja te faze školovanja. Čini se da su njihova očekivanja vjerojatno veća te vjeruju da će ih obrazovna institucija do kraja osposobiti za posao.

Ovakve pretpostavke nisu samo specifičnost ovog studija, već sindrom koji se javlja kod studenata i na drugim fakultetima. Visokoškolsko obrazovanje ne može u potpunosti osposobiti neki profil djelatnika za sva moguća radna mjesta na kojima se mogu zaposliti i pripremiti ih za sve situacije s kojima se mogu susresti u profesionalnom okruženju. ${ }^{12-14}$ Fizioterapeut može obavljati prilično različite aktivnosti s obzirom na to radi li u sportskom klubu, na neonatologiji ili u domu umirovljenika. Cilj akademskog obrazovanja jest dati kvalitetnu podlogu za sve oblike djelatnosti u pojedinoj struci koju će prvostupnici nadograđivati sami i/ili uz pomoć kolega na novom radnom mjestu.

Provjerili smo misle li ispitanici da je potrebno i dodatno usavršavanje osnovnih praktičnih vještina izvan propisanog plana i programa (12. tvrdnja). Većina studenata uglavnom se slaže $s$ tom tvrdnjom $(M=4,34)$, pri čemu prva skupina iskazuje statistički značajno veće slaganje. Apsolventi i prvostupnici fizioterapije smatraju da su razne dodatne edukacije, kojih je zaista priličan broj u dodatnom obrazovanju fizioterapeuta, važne za povećanje njihova osjećaja kompetentnosti. Taj nalaz u skladu je s njihovim kritičnijim mišljenjem o nekim aspektima obrazovanja, kao i o uvjetima rada u državnim ustanovama. Više važnosti pridaju usklađivanju rada nastavnika i mentora na praksi u svrhu prenošenja znanja.

U situaciji ponavljanja istraživanja anketu bi bilo potrebno dopuniti pitanjima o kompetencijama jer se tijekom ovog istraživanja javila indicija kako studenti nisu dovoljno upoznati s tim područjem. Pretpostavka bi bila da većina studenata nije upoznata s kompetencijama za koje će biti osposobljeni te se postavlja pitanje hoće li rezultati istih tvrdnji biti drugačiji nakon upoznavanja s kompetencijama, što otvara mogućnosti za nastavak ovakvog istraživanja. Također, bilo bi zanimljivo istraživanje proširiti na studente fizioterapije na drugim vi- sokoškolskim ustanovama kako bi se ustanovilo jesu li dobiveni rezultati specifičnost samo naše institucije ili je pojava tipična općenito za studij fizioterapije.

\section{Primjena teorije u praksi}

Studija Roskell i suradnika iz Velike Britanije ${ }^{4}$ razmatra pretpostavku da je sama priroda teorije multidimenzionalna i postoje različiti pogledi na nju i njezino odražavanje na praksu. Teorija se, prema studiji, dijeli na dvije vrste, formalnu i neformalnu. Formalna teorija odnosi se na objavljenju teoriju, bazu prenošenja znanja i otvorenija je za diskusiju, dok neformalna teorija ima svoj korijen u mudrosti prakse koja je razrađena kroz iskustvo i često je prikrivena i nije je moguće testirati. ${ }^{4}$ Stoga je neizbježno da postoji potencijal za razvoj sraza između teorije i prakse.

Prihvatimo li i primijenimo postojanje dviju vrsta teorija, odgovor na pitanje kako dolazi do sraza između teorije i prakse na studiju postaje jasniji. Studentima na kliničkoj praksi predstavlja se modificirani način rada, odnosno primjene teorije. Jaz između teorije i prakse događa se onog trenutka kada studenti bivaju aktivno uključeni u rad u zdravstvenim ustanovama. Studenti posjeduju znanja iz odslušane teorije i cilj im je to primijeniti u praksi. No formalna teorija nije u potpunosti primjenjiva u svim praktičnim uvjetima iz raznih razloga: manjak kadrova i vremena za kvalitetno obavljanje prakse, nedostatak opreme, uvriježeni način rada u pojedinoj instituciji. $U$ istraživanju se ispitalo je li potrebna koordinacija profesora predavača i mentora na praksi o predaji znanja studentima. Rezultati su pokazali da ispitanici prve skupine imaju izraženije mišljenje o tome od druge skupine studenata. Nedvojbeno je da do sraza dolazi u tom kada izostane koordinacija. Studenti žele primijeniti naučeno i pripremljeni su na određene zadatke koje smatraju da će ih zateći, no tada ih se uputi u nove načine rada, suvremenije načine, gdje naučena teorija često ispada zastarjela. No moguća je i obrnuta situacija: tijekom obrazovanja studenti se upoznaju s najnovijim dostignućima u svojoj struci, ali je zdravstveni sustav prevelik i trom ili jednostavno nema dovoljno resursa za uvođenje novih tehnika i aparata te edukaciju djelatnika za njihovu primjenu. To također može djelovati demoralizirajuće na studente koji „nadobudni" dolaze na radno mjesto, gdje ih može dočekati cinizam starijih i iskusnijih djelatnika koji godinama rade po ustaljenoj špranci.

Često nakon takvih saznanja dolazi do podijeljenog mišljenja studenata o tome kako tada učiti teoriju, koja je 
temelj svega, kada je ne mogu primijeniti. Svaki fizioterapeut na pojedinom radnom mjestu ima ili nema određene mogućnosti u smislu prostora, adekvatnih materijala i pomagala za rad te mora biti kreativan kako bi izvukao najbolje iz situacije. To zahtijeva prilagodbu načina rada i prilagodbu primjene naučenog. Studenti nauče standardizirani način rada, odnosno standardiziranu vještinu na kabinetskim vježbama, dok im se na kliničkim jedinicama zbog raznoraznih situacija demonstrira drugačije te dolazi do zbunjenosti. Kabinetske vježbe izvode se u kontroliranim i idealnim uvjetima za rad u svrhu svladavanja vještine rada. Radi se na „suradnim modelima” - studentima, dok u realnim uvjetima pacijenti mogu biti vrlo različitih stanja, raspoloženja, sposobnosti i motivacije. Važno je, uz teoriju, podučiti studente kroz kabinetske vježbe i seminare kako su uvjeti rada na nastavi idealni, a kako je stvarna situacija uglavnom drugačija. U državnim zdravstvenim institucijama nerijetko se događa situacija preopterećenosti pacijentima uz smanjen kapacitet osoblja i sredstava. Prema rezultatima, studenti se uglavnom slažu da fizioterapeuti zaposleni u državnim zdravstvenim ustanovama nemaju dovoljno potrebnog vremena ili sredstava za provođenje adekvatne fizioterapije sa svakim pacijentom ponaosob. S druge strane, većina je pretežno suglasna da u privatnim zdravstvenim ustanovama postoji potrebno vrijeme, kao i sredstva za adekvatno provođenje fizioterapije. Vrlo je važno uputiti studente u konkretnu situaciju i objasniti da se primjenjuje naučeno, međutim, potrebna je modifikacija s obzirom na situaciju. U svrhu toga, bitno je educirati ne samo studente nego i same mentore fizioterapeute na kliničkim jedinicama kako pristupiti studentima, što im pokazati i na koji način, kako komunicirati i potaknuti studente na rad.

Važno je i kvalitativno istraživanje norveških autora Skøiena i suradnika. ${ }^{15}$ Fokus istraživanja bio je na onome što su studenti smatrali važnim za učenje i kakva je kvaliteta, prema njihovu mišljenju, naučenog u kliničkim bazama. U odgovorima studenata iskristalizirale su se četiri teme: osjećaj pripadnosti i uključenosti, adekvatno vrijeme i prostor, pacijent u ulozi učitelja i važnost kolega studenata. Osjećaj pripadnosti i uključenosti odnosi se na mišljenje da su u pozitivnom okruženju, s profesionalnim entuzijazmom i energijom, studenti također opušteni i voljni postavljati pitanja, sudjelovati u diskusiji i iskoristiti danu situaciju za učenje. Jedan od studenata rekao je kako pomalo pratimo ljudske stope i da ako dobijemo dojam da smo nekome „slijepo crijevo” kojeg bi se radije riješio, radije ćemo se držati po strani i biti pasivni. Važno je biti poštovan, pa čak i ako si student. Adekvatno vrije- me i prostor odnosi se na način na koji je rad raspoređen i kako će se studenti naučiti tome prilagoditi. Sudionici su smatrali da je ključno imati dovoljno vremena za učenje kroz rad na kliničkim stanicama i prostoru gdje je mir kako bi se mogli koncentrirati na svoje postupke. Ako imaju dovoljno vremena, studenti se mogu pripremiti za susret s pacijentom, preispitati svoje postupke i odabrati najadekvatniji postupak za provođenje. $S$ druge strane, govoreći o prostoru, dostupnost potrebne opreme i mogućnosti za provođenje zamišljene terapije pokazali su se relevantnima. Sudionici studije izrazili su kako se pogledom na dobro opskrbljenu prostoriju za provođenje terapije pokazuje koliko je fizioterapija u određenoj ustanovi prioritet. Jedan od studenata navodi: „... Psihološ$\mathrm{ki}$, ako vidite prostor gdje su mjesne prilike neadekvatne, oprema je neadekvatna, u nekom trenutku zaključite da na ovome radnom mjestu nije privlačno biti fizioterapeut." ${ }^{\prime 5}$ Studenti fizioterapije imaju prilike vidjeti provođenje fizioterapije i u privatnim i u državnim ustanovama te smatraju da fizioterapeuti u državnim ili privatnim ustanovama nemaju isto raspoloživo vrijeme, kao ni jednako adekvatnu opremu za provođenje kvalitetne fizioterapije. Ovi rezultati otvaraju nove ideje pa bi buduća istraživanja na ovu temu mogla uključivati pitanja studentima gdje bi im bilo ugodnije raditi i učiti, u privatnim ili državnim ustanovama, te provjeriti bi li se rezultati podudarali $\mathrm{s}$ rezultatima istraživanja iz Norveške. Tema pacijent $u$ ulozi učitelja govori o mogućnosti prilagodbe studenta na različite pacijente, kako reagiraju, da postoje različiti pacijenti, različiti karakteri te da se moraju prilagoditi danoj situaciji. Svi sudionici spomenuli su važnost uloge pacijenta. Opisivali su da su s pacijentima unaprjeđivali svoje komunikacijske i praktične vještine te kliničko zaključivanje. Važnost kolega studenata uključuje osjećaj sigurnosti u nepoznatoj situaciji, a zatim i dijeljenje informacija i osjećaja. Unatoč tome što je svakom studentu važan društveni kontakt, studenti fizioterapije ipak su uglavnom suglasni s tim da najviše praktičnog znanja na praksi postižu individualnim angažmanom. S obzirom na to da su studenti na kliničkim jedinicama podijeljeni u skupine, često dolazi do situacije da su pojedinci vođe skupine, oni koji se ističu i prvi ulaze u kontakt s pacijentom, dok ostatak skupine ostaje po strani. Stoga je vrlo važno da svaki student ima priliku okušati se u komunikaciji s pacijentima i izvođenju barem određenog dijela fizioterapijskih postupaka. Ako su jedan ili dva studenta ti koji će se isticati, najviše će i dobiti od trenutačne situacije, najviše praktičnog znanja i usavršavanja, dok će ostali biti pasivni promatrači. Količina njihove pasivnosti na kraju će ovisiti o umijeću mentora da ih podjednako uključi u rad. 


\section{Postizanje zlatnog standarda}

Općepoznato je da je fizioterapija među profesijama u Europi koje su kasnije ušle u sustav visokog obrazovanja studenata. ${ }^{4} \mathrm{U}$ Republici Hrvatskoj razvoj visokog obrazovanja fizioterapeuta povezan je s osnivanjem prvog studija fizioterapije 1968. godine u Zagrebu, čemu je prethodio općeniti razvoj medicine i zdravstvenih profesija započet još davne 1790 . godine. ${ }^{16}$ S napretkom struke u profesiju važnu za fizioterapiju paralelno je tekao i napredak u obrazovnim programima za buduće fizioterapeute.

Australska studija Pattona i suradnika ${ }^{17}$ navodi kako trenutačno ne postoji zlatni standard u edukaciji budućih fizioterapeuta te da bi bilo idealno da postoji jedan specificirani način koji bi pomogao rješavanju svake nadolazeće situacije. Sveučilišta Australije teže idealu u edukaciji i bivaju izazvani pronaći načine kako svojim studentima osigurati kvalitetnu edukaciju i kvalitetno vodstvo. S tim ciljem sveučilišta nastoje upotrijebiti nekoliko strategija za procjenu kvalitete pružene edukacije na sveučilištu s profesorima te kolegama na kliničkim praksama. Da bi fizioterapeuti postali asistenti na kliničkim bazama (mentori), prolaze određene tečajeve o tome što i na koji način prenijeti studentima u cilju standardizacije prenošenja znanja. ${ }^{17}$ Kako bi postao profesor na australskom studiju za fizioterapeute, svaki kandidat mora posjedovati određene kompetencije za ispunjavanje uvjeta pri zapošljavaju. Jedna od strategija za postizanje zlatnog standarda na primjeru iz komore fizioterapeuta u Australiji jest ispunjavanje obrasca za ekvivalentnost stečenih kvalifikacija odnosno kompetencija. Jedan obrazac odnosi se na stečene kompetencije predavača, bilo teorije bilo prakse. Potrebni podaci obuhvaćaju: ime predavača, njegove kvalifikacije, stupanj registracije (...), odgovornosti na studiju te područja istraživanja. ${ }^{18}$ Drugi, obvezni obrazac sastoji se od sedam kompetencija za koje se smatra da svaki fizioterapeut mora posjedovati: kompetencije koje čine fizioterapeuta praktičarom, profesionalnost i etičnost, komunikativnost, motiviranost za napredovanje, sposobnost rada u timu, prenošenje znanja i upravljanje ljudima. Svaka velika kompetencija sastoji se od nekoliko manjih kompetencija, a studij koji je osoba pohađala ispunjava u obrascu putem kojeg se predmeta stječu. ${ }^{19}$ Obrasci se prilažu s ostalom dokumentacijom pri prijavi za radno mjesto. Navedeni primjer otvara put usklađivanja kompetencija u obrazovanju fizioterapeuta kroz izvedbu unutar nastavnih programa teorijskih i praktičnih zahtjeva za stjecanje ishoda učenja koji odgovaraju potrebama zajednice, odnosno pacijenata, korisnika i klijenata.
Teorija i praksa u fizioterapiji obuhvaćaju razmatranja dosadašnjih istraživanja u tijeku obrazovanja budućih fizioterapeuta. Rezultati ovog istraživanja pokazuju da je potrebno raditi na unaprjeđenju oba aspekta obrazovanja, s većim naglaskom na praktičan rad. Potrebno je omogućiti im da se osobno okušaju u što većem broju praktičnih aktivnosti. Zlatni standard u edukaciji budućih fizioterapeuta postiže se, uz poboljšanje kvalitete edukacije studenata, i edukacijom predavača i mentora.

Ovo istraživanje može potaknuti na promišljanje o dosadašnjem kurikulumu studija fizioterapije i potrebi jedinstvenog kurikuluma na razini svih visokoobrazovnih institucija u Hrvatskoj koje obrazuju fizioterapeute za ulaznu razinu rada, odnosno prvostupnike fizioterapije. Oblikovanje edukacije fizioterapeuta stalni je proces prilagodbe novim spoznajama u struci i znanosti, standardima u zdravstvenom sustavu, potrebama prakse, uz poboljšanje metodologije podučavanja, a sadašnji i bivši studenti izvrstan su i vrlo mjerodavan izvor informacija za moguća poboljšanja.

\section{Zaključak}

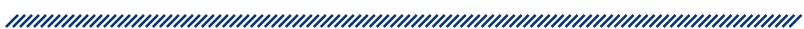

Studenti i prvostupnici fizioterapije smatraju kako bi na praktična znanja trebalo staviti veći naglasak u odnosu na teoriju. Također, slažu se s tvrdnjom o neusklađenosti znanja koje dobivaju u edukaciji i praktičnog rada s kojim se susreću na radilištima. Većina ispitanika ima stav kako bi bilo kvalitetnije da praksa iz određenog predmeta slijedi neposredno nakon teorijskog upoznavanja s predmetom.

Hipoteza o razlikovanju stavova studenata fizioterapije na trećoj godini studija u odnosu na skupinu sačinjenu od apsolvenata ili osoba na stažu djelomično je potvrđena, razlika je dobivena za šest od 16 tvrdnji. Primjerice, potonja skupina u većoj mjeri smatra da im je potrebno dodatno usavršavanje osnovnih praktičnih vještina te da je nužno usklađivanje znanja koje predaju nastavnici i mentori na praksi. U manjoj mjeri se slažu s tvrdnjom da je dosadašnja količina kliničke nastave dovoljna za rad u praksi nakon studija. 


\section{Referencije}

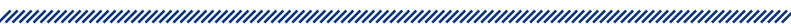

1. Zdravstveno Veleučilište u Zagrebu. Studijski program stručnog studija fizioterapije (izmjene i dopune). Zagreb: Zdravstveno Veleučilište u Zagrebu; 2016. str. 4. Dostupno na: https://www.zvu.hr/wp-content/uploads/ FT.pdf (pristupljeno 25.4.2019.).

2. Bezić Ž. Teorija i praksa. Crkva u svijetu. 1982; 17(4): 344353. Dostupno na: https://hrcak.srce.hr/89979 (pristupljeno 8.5.2019.).

3. Leksikografski zavod Miroslav Krleža. Hrvatska enciklopedija. Dostupno na: http://www.enciklopedija.hr/ natuknica.aspx?id=60872 (pristupljeno 25.4.2019.).

4. Roskell C, Hewison A, Wildman S. The theory-practice gap and physiotherapy in the UK: Insights from the nursing experience. Physiotherapy Theory and Practice. 1998; 14: 223-233.

5. Grčko-hrvatski rječnik. VII izdanje. Zagreb: Školska knji-

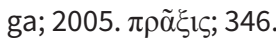

6. Hrvatska Akademska i Istraživačka Mreža (CARNET). Studijski programi. Dostupno na: https://www.postanistudent.hr/Ucilista/Nositelji.aspx (pristupljeno 8.5.2019.).

7. Zdravstveno Veleučilište u Zagrebu. Nastavni plan i program. Dostupno na: https://www.zvu.hr/static/np/ npip/35.html (pristupljeno 8.5.2019.).

8. Sveučilište u Rijeci, Fakultet zdravstvenih studija. Nastavni plan stručnog studija fizioterapije. Dostupno na: http://www.fzsri.uniri.hr/files/NASTAVA/Nastavni_planovi_2018_19/NP18-19VFT.pdf (pristupljeno 8.5.2019.).

9. Libertas međunarodno sveučilište. Nastavni plan i program. Dostupno na: https://www.libertas.hr/wpcontent/uploads/2017/05/Nastavni-plan-i-program.pdf (pristupljeno 8.5.2019.).
10. Zdravstveno veleučilište u Zagrebu. Stručna praksa na preddiplomskom studiju fizioterapije. Dostupno na: https://www.zvu.hr/strucni-studij-fizioterapije-strucnapraksa/ (pristupljeno 30.4.2019.).

11. Šulenti Begi J. Kompetencije učitelja primarnoga obrazovanja za poučavanje glazbe. Život i škola. 2013; 29 (1): 252-269.

12. Blažević D. Nastavničke kompetencije nastavnika stručno-teorijskih sadržaja. Diplomski rad. Rijeka: Odsjek za pedagogiju Filozofskog fakulteta Sveučilišta u Rijeci; 2018.

13. Horvat $M$, Kolačko D, Novak M, Bašić J. Promišljanja o etičkim dilemama u pripremi studenata socijalne pedagogije za djelovanje u praksi. Kriminologija i socijalna integracija. 2011; 19(2): 1-122.

14. Jukić T, Elez M. Osposobljenost studenata nastavničkih studija za rad s djecom s govornim teškoćama u redovitoj nastavi. Pedagogijska istraživanja. 2013; 10(1): 135-148.

15. Skøien A, Vågstøl U, Raaheim A. Learning physiotherapy in clinical practice: Student interaction in a professional context. Physiotherapy Theory and Practice. 2009; 25(4): 268-278.

16. Medicinski fakultet Sveučilišta u Zagrebu. Osnutak Medicinskog fakulteta u Zagrebu. Dostupno na: http://mef. unizg.hr/o-nama/povijest-misija-vizija/osnutak-medicinskog-fakulteta-u-zagrebu (pristupljeno 20.5.2019.).

17. Patton N, Higgs J, Smith M. Using theories od learning in workplaces to enhance physiotherapy clinical education. Physiotherapy Theory and Practice. 2013; 29(7): 493-503.

18. Australian Physiotherapy Council. Equivalence of qualification - Academic staffing profile template. Dostupno na: https://physiocouncil.com.au/wp-content/uploads/2018/ 03/EQ-Staffing-Profile-Template-LOCKED.docx (pristupljeno 15.5.2019.)

19. Australian Physiotherapy Council. Dostupno na: https:// physiocouncil.com.au/wp-content/uploads/2018/03/ TEMPLATE-Map-Physiotherapy-Practice-ThresholdsLocked-2018.docx (pristupljeno 15.5.2019.). 


\section{OPINIONS OF STUDENTS AND BACHELORS OF PHYSIOTHERAPY ON THEORETICAL AND PRACTICAL TEACHING}

1 Dora Jurički

1 Olivera Petrak

1 Snježana Schuster

1 University of Applied Health Sciences, Zagreb, Mlinarska 38, Croatia

\section{Abstract \\ ,A physiotherapist should have specific skills and knowl- edge.... This phrase refers to professional competenc- es required for adequate assessment of the patient's condition, making a specific diagnosis based on the assessment, and performing the physiotherapeutic in- tervention. It is emphasized that in education, it is as important to learn the theory, as it is to master the prac- tical training.}

Aim: To determine the students' beliefs towards the quality and compatibility of the theoretical and practical professional content, and whether there is a significant difference between the opinions of third-year students in relation to students in their senior year and bachelors of physiotherapy.

Methods: The research was conducted on undergraduate students and bachelors of physiotherapy at the University of Applied Health Sciences in Zagreb in 2019. The research included 88 participants divided into two groups. The first group included students in their senior year and students with a degree in physiotherapy, and the second group included students in the last year of the full-time study of physiotherapy. At the time of answering the questionnaire, the second group was in clinical training.

Results: Participants feel that there needs to be a greater emphasis on practical knowledge and that there is a mismatch between the theoretical knowledge and the practical work they experience on site. Participants believe that clinical training on a particular topic should be given immediately after the theoretical introduction in order to achieve better quality. In addition, the participants emphasize the importance of the individual commitment of each student. The first group believes to a higher degree that there is a need for additional training in basic practical skills and that harmonization between teachers and mentors in clinical workplaces is necessary.

Conclusion: The results of this research show the greater need for the improvement of current theoretical and practical knowledge with the aim of advancing practical work in physiotherapy, with the possibility of creating a unique curriculum for the education of future bachelors of physiotherapy in Croatia. The golden standard in the education of future physiotherapists is achieved with both the improvement of the quality of education of students and with the training for lecturers and clinical workplace mentors.

Keywords: physiotherapy, theory, practical training, students, curriculum 